\title{
Prebiotics and butyric acid can replace colistin as a growth promoter for nursery piglets
}

[Prebióticos e ácido butírico podem substituir a colistina como promotor de crescimento para leitões em fase de creche]

\author{
C. A. Silva ${ }^{1}$, C.P. Dias ${ }^{2}$, M.A. Callegari ${ }^{2}$, A.M. Bridi ${ }^{1}$, R.K.S. Santos ${ }^{1}$, \\ F.G. Luiggi ${ }^{3}$, V.L. Santos ${ }^{3}$, J.B. Silva ${ }^{3}$
}

${ }^{1}$ Universidade Estadual de Londrina (UEL) - Londrina, PR

${ }^{2}$ AKEI Animal Research - Fartura, SP.

${ }^{3}$ Yes Sinergy do Brasil Agroindustrial Ltda - Campinas, SP

\begin{abstract}
This study aimed to assess different prebiotic concentrations and principles, in addition to calcium butyrate, aiming to replace colistin as a growth promoter. The sample consisted of 120 piglets weaned at 22 days old with mean initial weight of $5.475 \pm 0.719 \mathrm{~kg}$. The animals were assigned to random blocks in six treatments corresponding to the use of the following dietary additives: T1) colistin (40 ppm); T2) $\beta$-glucan/mannanoligosaccharides $(0.2 \%)$; T3) calcium butyrate $(0.1 \%)$; T4) $\beta$-glucan/mannan-oligosaccharides $(0.1 \%)+$ fructooligosaccharides $(0.01 \%)+$ galactooligosaccharides $(0.09 \%)$; T5) $\beta$-glucan/mannan-oligosaccharides $(0.1 \%)+$ fructooligosaccharides $(0.03 \%)+$ galactooligosaccharides $(0.07 \%)$; and $\mathrm{T} 6) \beta$-glucan/mannanoligosaccharides $(0.1 \%)+$ fructooligosaccharides $(0.05 \%)+$ galactooligosaccharides $(0.05 \%)$. The results showed no difference among treatments for the performance parameters in any of the phases evaluated. For diarrhea incidence and intensity, the results indicated that the treatments with alternative additives had similar effects as the group treated with colistin. A significant difference was found for the profile of propionic acid $(0.23 \%$ colistin and $0.32 \%, 0.36 \%, 0.37 \%$ additives $)$ and total fatty acids $(0.67 \%$ colistin and $0.97 \%$ additives $)$ values in the caecum. The supplementation with different compositions and concentrations of prebiotics and butyric acid may viably replace colistin in controlling diarrhea and modulating volatile fatty acid production in the caecum.
\end{abstract}

Keywords: additives, efficiency, organic acids, performance

\section{RESUMO}

O objetivo deste trabalho foi avaliar as diferentes concentrações e princípios de prebióticos e do butirato de sódio, visando substituir a colistina como promotor de crescimento. Foram utilizados 120 leitões, desmamados aos 22 dias de idade, com peso médio inicial de 5,475 $\pm 0,719 \mathrm{~kg}$. Os animais foram distribuídos em blocos ao acaso, em seis tratamentos, que corresponderam ao uso dos seguintes aditivos dietéticos: T1) colistina (40ppm); T2) $\beta$-glucanos/mananoligossacarídeos (0,2\%); T3) butirato de cálcio (0,1\%); T4) $\beta$-glucanos/mananoligossacarídeos $(0,1 \%)+$ frutoligossacarídeos $(0,01 \%)+$ galactoligossacarídeos $(0,09 \%)$; T5) $\beta$-glucanos/mananoligossacarídeos $(0,1 \%)+$ frutoligossacarídeos $(0,03 \%)+$ galactoligossacarídeos (0,07\%); e T6) B-glucanos/mananoligossacarídeos $(0,1 \%)+$ frutoligossacarídeos $(0,05 \%)+$ galactoligossacarídeos $(0,05 \%)$. Os resultados mostraram que não houve diferença entre os tratamentos para nenhum dos parâmetros de desempenho em nenhuma das fases avaliadas. Para a incidência e a intensidade de diarreia, os resultados apontam que os tratamentos com os aditivos alternativos apresentaram efeitos semelhantes aos do grupo tratado com colistina. Foi encontrada diferença significativa para perfil dos ácidos graxos propiônicos $(0,23 \%$ colistina e $0,32 \%, 0,36 \%, 0,37 \%$ aditivos) e ácidos totais $(0,67 \%$ colistina e $0,97 \%$ aditivos) no ceco. A suplementação com diferentes composições e concentrações de prebióticos e do ácido butírico pode substituir a colistina de forma viável no controle da diarreia e na modulação da produção volátil de ácidos graxos no ceco.

Palavras-chave: aditivos, eficiência, ácidos orgânicos, performance

Recebido em 2 de julho de 2019

Aceito em 14 de novembro de 2019

E-mail:rita.zoo@live.com 


\section{INTRODUCTION}

In intensive pig farming, post-weaning challenges are commonly associated to gastrointestinal tract immaturity and to low immunocompetence, which results in malfunctioning of the intestinal barrier and predisposition to diarrhea, thus impairing piglet performance (Jayaraman and Nyachoti, 2017).

To minimize such damage, growth-promoting antibiotics (GPA) have often been used in subtherapeutic doses in feed for years, with effective results in reducing pathogenic microorganism populations that adhere to the intestinal mucosa and subsequent reduction in toxin production and improving animal performance (Gavioli et al., 2013; Liu et al., 2018). Among several antibiotics available for this purpose, colistin, which action is selective for Gram-negative enteric bacilli, particularly Escherichia coli, is one of the most effective molecules employed in pig farming (Mendes and Burdmann, 2009). However, in face of the recent identification of human resistance to the antibiotic, its use as a GPA has been banned worldwide.

The consequences of removing colistin from pig farming, associated with the restriction to other GPAs, have driven interest by the industry in recent years to the use of alternative additives. Of the many actions prebiotics have on weaned piglets, the modulation of the beneficial microbiota in the gastrointestinal tract stands out. These agents use prebiotics as substrate for their development in place of pathogenic microorganisms (Hustkins et al., 2016), which improves nutrient use, reduces diarrhea incidence, and enhances weight gain and feed efficiency (Silva and Nornberg, 2003).

As for butyric acid, its antimicrobial action (Biagi et al., 2007) and role in increasing the production of short-chain fatty acids stand out. Such actions contribute to lowering intestinal $\mathrm{pH}$ and reduce the capacity of pathogens to colonize the intestine, besides serving as energy supply for enterocytes, thus favoring intestinal mucosa renewal (Liu et al., 2018).

Nonetheless, the multi-factorial nature of actions related to weaning associated with the variety of prebiotics and acidifiers available, as well as the conditions under which they are used in face of the principles and different doses and use periods employed, must be seen as variables that may result in still inconsistent responses to these additives when compared to GPAs.

This study aimed to assess dietary supplementation with different prebiotic additive at different concentrations in addition to sodium butyrate on nursery piglet performance, diarrhea control, and volatile fatty acid (VFA) profile in the caecum in order to replace colistin as a growth promoter.

\section{MATERIAL AND METHODS}

All procedures adopted in this research were previously reviewed and approved by the Committee of Ethics on Animal Research and Experimentation of Akei Animal Research under protocol no. 013/2018.

One hundred and twenty Agroceres PIC piglets (60 barrows and 60 gilts) weaned at 22 days old with mean initial weight of $5.475 \pm 0.719 \mathrm{~kg}$ were evaluated for 42 days ( 22 to 64 days of age).

The piglets were assigned to random blocks according to their weight and sex and submitted to six treatments with six repetitions each (three piglets of the same sex per pen represented the experimental unit). The treatments corresponded to the use of the following dietary additives: T1) colistin (40 ppm); T2) $\beta$-glucan/mannanoligosaccharides $(0.2 \%)$; T3) calcium butyrate $(0.1 \%)$; T4) $\beta$-glucan/mannan-oligosaccharides $(0.1 \%)+$ fructooligosaccharides $(0.01 \%)+$ galactooligosaccharides $\quad(0.09 \%) ; \quad$ T5) $\beta$ glucan/mannan-oligosaccharides $(0.1 \%)+$ fructooligosaccharides $(0.03 \%)+$ galactooligosaccharides $(0.07 \%)$; and T6) $\beta$ glucan/mannan-oligosaccharides $(0.1 \%)+$ fructooligosaccharides $\quad(0.05 \%)+$ galactooligosaccharides $(0.05 \%)$.

The animals were housed in $2.55 \mathrm{~m}^{2}$ masonry pens with fully slatted floor, nipple drinking trough, and linear feeding troughs. The pens were heated using $200 \mathrm{~W}$ infrared light bulbs placed at the center of the pens $0.70 \mathrm{~m}$ above the ground and the barn curtains were also managed for temperature control.

The experimental feeds were isonutritive and isoenergetic and were prepared following the 
minimum recommendations by Rostagno et al. (2011) split into three phases: pre-initial I, preinitial II, and initial (Tab. 1). The feed was provided ad libitum and the animals had free access to water.

Table 1. Composition and calculated nutritional and energy values of the experimental feeds for nursery piglets

\begin{tabular}{|c|c|c|c|}
\hline Ingredients & Pre-initial I & Pre-initial II & Initial \\
\hline Corn $7 \%$ & 55.103 & 62.621 & 68.239 \\
\hline Soybean meal 47\% & 22.000 & 25.000 & 28.300 \\
\hline Star Pro 25 (Auster) & 5.000 & 2.000 & \\
\hline Prius L70 (Auster) & 10.972 & 4.388 & - \\
\hline Extruded soybean $36 \%$ & 2.600 & 2.000 & \\
\hline Calcitic lime $38 \%$ & 0.750 & 1.150 & 1.500 \\
\hline Dicalcium phosphate $18 \%$ & 0.300 & 0.350 & 0.350 \\
\hline Table salt & 0.440 & 0.460 & 0.480 \\
\hline L-lysine & 0.470 & 0.370 & 0.230 \\
\hline DL-Methionine & 0.140 & 0.090 & 0.010 \\
\hline L-threonine & 0.175 & 0.105 & 0.025 \\
\hline L-tryptofan & 0.030 & - & - \\
\hline L-valine $96.5 \%$ & 0.150 & 0.050 & \\
\hline Colin chloride $60 \%$ & 0.047 & 0.038 & 0.032 \\
\hline Phytase (50 g/ton) & 0.005 & 0.005 & 0.005 \\
\hline Antioxidant & 0.010 & 0.010 & 0.010 \\
\hline Vitamin premix ${ }^{1}$ & 0.150 & 0.150 & 0.150 \\
\hline Mineral premix ${ }^{2}$ & 0.100 & 0.100 & 0.100 \\
\hline Inert (caulin or treatments ${ }^{3}$ ) & 1.556 & 1.111 & 1.136 \\
\hline \multicolumn{4}{|l|}{ Nutrients } \\
\hline Moisture, $\%$ & 10.596 & 11.562 & 12.304 \\
\hline Metabolizable energy (kcal/kg) & 3.365 & 3.274 & 3.207 \\
\hline Crude protein, $\%$ & 18.500 & 18.500 & 18.500 \\
\hline Ether extract, \% & 2.421 & 2.416 & 2.137 \\
\hline Crude fiber, $\%$ & 2.604 & 2.897 & 3.069 \\
\hline Mineral matter, $\%$ & 4.591 & 4.445 & 4.402 \\
\hline Lactose, $\%$ & 9.760 & 3.904 & \\
\hline Calcium, \% & 0.650 & 0.754 & 0.846 \\
\hline Total phosphorus, $\%$ & 0.481 & 0.449 & 0.413 \\
\hline Available phosphorus, $\%$ & 0.400 & 0.346 & 0.296 \\
\hline Sodium, $\%$ & 0.298 & 0.248 & 0.218 \\
\hline Electrolyte balance, $\mathrm{mEq} / \mathrm{kg}$ & 174.103 & 175.067 & 179.736 \\
\hline Digestible lysine, $\%$ & 1.249 & 1.148 & 1.028 \\
\hline Digestible methionine + cysteine, $\%$ & 0.687 & 0.639 & 0.564 \\
\hline Digestible tryptophan, $\%$ & 0.213 & 0.190 & 0.195 \\
\hline Digestible threonine, $\%$ & 0.749 & 0.690 & 0.620 \\
\hline
\end{tabular}

${ }^{1}$ levels per kg of the vitamin premix: vitamin A (min) 6,000 UI; vitamin D3 (min) 1,500 UI; vitamin E (min) 15,000mg; vitamin K3 (min) 1,500mg; vitamin B1 (min) 1,350mg; vitamin B2 4,000mg; vitamin B6 2,000mg; vitamin B12 (min) 20mg; niacin ( $\mathrm{min})$ 20,000mg; pantothenic acid ( $\mathrm{min})$ 9,350mg; folic acid (min) 600mg; biotin (min) 80mg; selenium(min) $300 \mathrm{mg}$.

${ }^{2}$ levels per kg of the mineral premix: iron ( $\left.\min \right) 100 \mathrm{mg}$; copper (min) 10mg; manganese (min) $40 \mathrm{~g}$; cobalt (min) $1,000 \mathrm{mg}$; zinc $(\mathrm{min}) 100 \mathrm{mg}$; iodine $(\mathrm{min}) 1,500 \mathrm{mg}$.

$\left.{ }^{3} \mathrm{~T} 1\right)$ colistin (40 ppm); T2) $\beta$-glucan/mannan-oligosaccharides $(0.2 \%)$; T3) calcium butyrate $(0.1 \%)$; T4) $\beta$ glucan/mannan-oligosaccharides $(0.1 \%)+$ fructooligosaccharides $(0.01 \%)+$ galactooligosaccharides $(0.09 \%)$; T5) $\beta$ glucan/mannan-oligosaccharides $(0.1 \%)+$ fructooligosaccharides $(0.03 \%)+$ galactooligosaccharides $(0.07 \%)$; and T6) $\beta$-glucan/mannan-oligosaccharides $(0.1 \%)+$ fructooligosaccharides $(0.05 \%)+$ galactooligosaccharides $(0.05 \%) ;(5: 5)$ 
Daily feed intake, daily weight gain, and feed conversion were assessed for each phase and over the entire study period.

Diarrhea incidence and intensity were assessed throughout the experiment according to Vassalo et al. (1997) and were classified as feces with regular consistency (0), soft feces (1), pasty feces (2), and aqueous feces (3). Scores 0 and 1 meant the feces were not considered as diarrhea, unlike scores 2 and 3.

By the end of the experimental period (at 64 days of age), six animals from each treatment were slaughtered (chosen based on the mean weight of the pen) and their caecum contents were collected to determine the profile of short-chain volatile fatty acids (acetic, butyric, and propionic) according to Erwin et al. (1961) using gas chromatography (FOCUS GC; Thermo Scientific - equipped with a glass column $3 \mathrm{~m}$ in length and $0.25 \mathrm{~m}$ in diameter packaged with 80/100 Carbopack B-DA/4\% Carbowax 20W).
The data were submitted to analysis of variance and the means were compared by Tukey's test using the statistical software $\mathrm{R}$ version 3.5.0. Chisquared test was used for non-parametric data. Both tests employed $\alpha$ of 0.05 as significance threshold, which indicated trends when its value was below 0.10 .

\section{RESULTS AND DISCUSSION}

No difference was found among treatments for any performance parameters in any of the phases evaluated or over the total experimental period (Tab. 2). That indicates that, regardless of the program adopted, the alternative additives to colistin acted positively and were aligned with the trends towards GPA replacement. The results were similar to those reported by Luna et al. (2015), who, when working with nursery piglets fed diets supplemented with mannanoligosaccharide $(0.33$ and $1.83 \mathrm{~g} / \mathrm{kg}$ feed $)$, $\beta$-glucan $(0.5 \mathrm{~g} / \mathrm{kg}$ feed $)$, and colistin $(0.25 \mathrm{~g} / \mathrm{kg}$ feed), found no influence on weight gain, feed intake, or feed conversion among treatments.

Table 2. Mean values of daily feed intake (DFI), daily weight gain (DWG), and feed conversion (FC) for nursery piglets, according to the experimental treatments

\begin{tabular}{|c|c|c|c|c|c|c|c|c|}
\hline \multirow{2}{*}{$\begin{array}{l}\text { Parameters } \\
(\mathrm{kg})\end{array}$} & \multicolumn{6}{|c|}{ Treatments } & \multirow[b]{2}{*}{$\mathrm{CV}(\%)$} & \multirow[b]{2}{*}{$\mathrm{P}$-value } \\
\hline & $\mathrm{T} 1$ & $\mathrm{~T} 2$ & T3 & $\mathrm{T} 4$ & T5 & T6 & & \\
\hline \multicolumn{9}{|c|}{ Pre-initial phase I } \\
\hline DFI & 0.222 & 0.210 & 0.212 & 0.209 & 0.217 & 0.199 & 9.95 & 0.695 \\
\hline DWG & 0.160 & 0.147 & 0.153 & 0.145 & 0.105 & 0.182 & 47.70 & 0.517 \\
\hline $\mathrm{FC}$ & 1.549 & 1.746 & 1.859 & 1.941 & 1.680 & 1.227 & 52.97 & 0.821 \\
\hline \multicolumn{9}{|c|}{ Pre-initial phase II } \\
\hline DFI & 0.391 & 0.381 & 0.372 & 0.394 & 0.374 & 0.360 & 14.61 & 0.442 \\
\hline DWG & 0.273 & 0.272 & 0.237 & 0.270 & 0.247 & 0.247 & 29.18 & 0.592 \\
\hline $\mathrm{FC}$ & 1.518 & 1.487 & 1.688 & 1.994 & 1.526 & 1.529 & 23.70 & 0.139 \\
\hline \multicolumn{9}{|l|}{ Initial phase } \\
\hline DFI & 0.780 & 0.737 & 0.750 & 0.712 & 0.721 & 0.758 & 13.96 & 0.840 \\
\hline DWG & 0.380 & 0.346 & 0.334 & 0.345 & 0.338 & 0.336 & 23.38 & 0.897 \\
\hline $\mathrm{FC}$ & 2.161 & 2.121 & 2.279 & 2.232 & 2.147 & 2.282 & 15.80 & 0.919 \\
\hline \multicolumn{9}{|l|}{ Total } \\
\hline DFI & 0.463 & 0.445 & 0.445 & 0.439 & 0.437 & 0.439 & 10.92 & 0.932 \\
\hline DWG & 0.260 & 0.249 & 0.247 & 0.229 & 0.228 & 0.248 & 20.13 & 0.809 \\
\hline $\mathrm{FC}$ & 1.842 & 1.786 & 1.936 & 1.990 & 1.931 & 1.862 & 14.29 & 0.751 \\
\hline
\end{tabular}

T1) colistin (40 ppm); T2) $\beta$-glucan/mannan-oligosaccharides $(0.2 \%)$; T3) calcium butyrate $(0.1 \%)$; T4) $\beta$ glucan/mannan-oligosaccharides $(0.1 \%)+$ fructooligosaccharides $(0.01 \%)+$ galactooligosaccharides $(0.09 \%)$; T5) $\beta$ glucan/mannan-oligosaccharides $(0.1 \%)+$ fructooligosaccharides $(0.03 \%)+$ galactooligosaccharides $(0.07 \%)$; and T6) $\beta$-glucan/mannan-oligosaccharides $(0.1 \%)+$ fructooligosaccharides $(0.05 \%)+$ galactooligosaccharides $(0.05 \%)$.

Investigations on alternative additives to GPAs have been recurring in recent years. Santos et al. (2010), when working with different dietary levels of mannanoligosaccharide $(0.25 \%, 0.50 \%$, and $0.75 \%$ ), compared to diets supplemented with neomycin sulfate $(56 \mathrm{ppm})$, found no distinct advantages $(\mathrm{P}>0.05)$ among treatments. Visentini et al. (2008), when using fructooligosaccharides 
(0.2\%), and Park et al. (2018), when assessing different $\beta$-glucan levels (0.1, 0.2 and $0.4 \%$ ) versus tiamulin $(30 \mathrm{ppm})$, also found no difference in performance among treatments for nursery piglets.

A similar effect as that observed for the group treated with colistin was seen for butyrate, likely due to the increase in nutrient digestibility and improved bioavailability of amino acids this additive provides, as discussed by Moquet et al. (2017).

Most studies with sodium butyrate have been carried out with nursery animals and have achieved several positive performance results, particularly in weight gain, as reported by Chiofalo et al. (2014) when using 440 ppm doses and by Hanczakowska et al. (2014) when using $3.000 \mathrm{ppm}$. However, the contradiction in results of some studies that used butyrate may be related to diet composition and to the maturity state of piglet intestines (Biagi et al., 2007).

Controversies regarding the performance results when using prebiotics compared to GPAs, with advantages to the latter (Visentini et al., 2008; Santos et al., 2010) are considered relatively common, particularly in cases in which conditions of high sanitary challenge are found (Gebbink et al., 1999). However, some results contradict that, which allows the inference that the bactericidal/bacteriostatic action of some GPAs against gastrointestinal tract bacteria may compromise the equilibrium of this microbiome and, in some cases, lead to increased epithelial desquamation and worse villous/crypt ratio (Gavioli et al., 2013). GPAs may also compromise the fermentative efficiency of the intestinal microbiota, responsible for producing VFAs, which represent a major energy source for enterocyte turnover (Lin and Visek, 1991).

On the other hand, particularly in the first weeks post-weaning, feed intake is low, partially due to the immature digestive system, which impairs the immune system and performance and increases the proliferation of diarrhea-causing bacteria (Jayaraman and Nyachoti, 2017). Prebiotics and acids have roles that are closely related to this scenario, minimizing the damage inherent to this critical step in case of immaturity of the gastrointestinal tract (Biagi et al., 2007) and immune system (Wu et al., 2017), thus enhancing nutrient use (Silva and Nornberg, 2003).

For diarrhea incidence and intensity (Tab. 3), the results for scores 2, 3, and total incidence $(2+3)$ indicated that the treatments with alternative additives (T2, T3, T4, T5, and T6) had similar effects as the group treated with colistin. However, for score 3, the animals in groups T4 and T6, respectively $\beta$-glucan/mannanoligosaccharides $(0.1 \%)+$ fructooligosaccharides $(0.01 \%)+$ galactooligosaccharides $(0.09 \%)$ and $\beta$ glucan/mannan-oligosaccharides $(0.1 \%)+$ fructooligosaccharides $\quad(0.05 \%)+$ galactooligosaccharides $(0.05 \%)$ had better results than the other treatments. Adversely, T5, which contained the same prebiotic additive of $\mathrm{T} 4$ and T6, i.e., $\beta$-glucan/mannan-oligosaccharides $(0.1 \%)+$ fructooligosaccharides $(0.03 \%)+$ galactooligosaccharides $(0.07 \%)$, but a different ratio of prebiotic additive, did not have the same behavior as those groups.

Table 3. Percentages of diarrhea scores for nursery piglets, according to the experimental treatments

\begin{tabular}{|c|c|c|c|c|}
\hline \multirow{2}{*}{ Treatments } & \multirow{2}{*}{ Notes } & \multicolumn{3}{|c|}{ Fecal score $(\%)$} \\
\hline & & Grade II & Grade III & Grades II + III \\
\hline $\mathrm{T} 1$ & 882 & $36 b$ & $27 b$ & $63 b$ \\
\hline $\mathrm{T} 2$ & 882 & $42 b$ & $24 b$ & $66 b$ \\
\hline $\mathrm{T} 3$ & 882 & $33 \mathrm{ba}$ & $20 b$ & $53 b$ \\
\hline $\mathrm{T} 4$ & 882 & $27 \mathrm{ba}$ & $11 \mathrm{a}$ & $38 \mathrm{a}$ \\
\hline T5 & 882 & $41 b$ & $38 b$ & $79 b$ \\
\hline T6 & 882 & $23^{a}$ & $17 \mathrm{a}$ & $40 \mathrm{a}$ \\
\hline $\begin{array}{l}\text { ucan/mannan- } \\
\text { glucan/mannar } \\
\text { differences ac }\end{array}$ & cchari & $\begin{array}{l}\text { ctooligosac } \\
\text { ructooligos } \\
<0.05)\end{array}$ & $\begin{array}{l}\text { 6) + galacto } \\
5 \% \text { ) + gala }\end{array}$ & $\begin{array}{l}\text { yrate }(0.1 \%) ; \mathrm{T} \\
\text { larides }(0.09 \%) \text {; T } \\
\text { arides }(0.07 \%) \text {; an } \\
\text { charides }(0.05 \%) \text {. }\end{array}$ \\
\hline
\end{tabular}


The results match those reported by Grela et al. (2006), who, when assessing the frequency of diarrhea in piglets from birth to 84 days of age, found that adding $3,000 \mathrm{mg} / \mathrm{kg}$ and $5,000 \mathrm{mg} / \mathrm{kg}$ mannanoligosaccharide and fructooligosaccharide, respectively, decreased diarrhea incidence. Such results are attributed to the possible improvement of the immune system and epithelium integrity (Wu et al., 2017) and match the findings by Budiño et al. (2010), Assis et al. (2014), and Luna et al. (2015), who used fructooligosaccharides, mannanoligosaccharides, and $\beta$-glucans + mannanoligosaccharides versus GPA respectively, and found no differences among the treatments.

Prebiotics may induce metabolic processes that are beneficial to the health of the host ecosystem due to the easy degradability of the bonds in the structure of fructooligosaccharides and galactooligosaccharides by certain enzymes, such as $\beta$-fructosidase and $\beta$-galactosidase, commonly associated with beneficial bacteria of the genus Bifidobacterium (Markowiakautor and Śliżewska, 2018), which feed on those sugars, multiply, and colonize the tract.

In this line, the use of mannanoligosaccharides has been recommended as it reduces colonization by pathogenic bacteria and, consequently, the incidence of post-weaning diarrhea (Silva and Nörnberg, 2003). The presence of fructooligosaccharides also improves the condition of the intestinal wall (villi), which increases absorption capacity (Budinõ et al., 2010).

Kotunia et al. (2004) supplemented diets of twoweek-old suckling pigs with butyrate $(3,000 \mathrm{mg} / \mathrm{kg}$ feed) for seven days and found increased villous height, crypt depth, and jejunum and ileum mucosa thickness compared to animals that were not fed supplementation. Mazzoni et al. (2008), when supplementing piglet diet with sodium butyrate $(3,000 \mathrm{mg} / \mathrm{kg})$ before (four to 28 days of age) and after weaning (29 to 40 days of age), observed an increase in positive parietal, enteroendocrine, and somatostatin cells, which enhanced the gastric mucosa. The consequences were lower intestinal damage and fewer cases of diarrhea. On the other hand, unprotected butyrate may have limited action in this segment of the intestine as it can experience high absorption in the upper parts of the gastrointestinal tract (Piva et al., 2007).

A significant difference in fatty acids in the caecum (Tab. 4) was found for the profile of propionic acid and total fatty acids (acetic, butyric, and propionic). For propionic acid, T3, T5, and T6, respectively, $\beta$-glucan/mannanoligosaccharides $\quad(0.1 \%)+$ fructooligosaccharides $\quad(0.03 \%)+$ galactooligosaccharides $\quad(0.07 \%)$ and $\beta$-glucan/mannanoligosaccharides $(0.1 \%)+$ fructooligosaccharides $\quad(0.05 \%)+$ galactooligosaccharides $(0.05 \%)$, were better than the control treatment (40 ppm colistin) and did not differ $(\mathrm{P}>0.05)$ from the other treatments.

Table 4. Mean values of fatty acids in the caecum of piglets at 64 days of age according to the experimental treatments

\begin{tabular}{ccccc}
\hline Treatments & Butyric (\%) & Acetic $(\%)$ & Propionic $(\%)$ & Total $(\%)$ \\
\hline T1 & 0.13 & 0.32 & $0.23 \mathrm{~b}$ & $0.67 \mathrm{~b}$ \\
T2 & 0.14 & 0.36 & $0.29 \mathrm{ab}$ & $0.79 \mathrm{ab}$ \\
T3 & 0.18 & 0.38 & $0.32 \mathrm{a}$ & $0.87 \mathrm{ab}$ \\
T4 & 0.29 & 0.37 & $0.31 \mathrm{ab}$ & $0.97 \mathrm{a}$ \\
T5 & 0.16 & 0.35 & $0.36 \mathrm{a}$ & $0.87 \mathrm{ab}$ \\
T6 & 0.17 & 0.38 & $0.37 \mathrm{a}$ & $0.93 \mathrm{ab}$ \\
\hline P-value & 0.288 & 0.457 & 0.001 & 0.050 \\
CV \% & 73.91 & 17.70 & 20.64 & 21.39 \\
\hline
\end{tabular}

$\mathrm{T} 1)$ colistin (40 ppm); T2) $\beta$-glucan/mannan-oligosaccharides $(0.2 \%) ;$ T3) calcium butirate $(0.1 \%)$; T4) $\beta$ glucan/mannan-oligosaccharides $(0.1 \%)+$ fructooligosaccharides $(0.01 \%)+$ galactooligosaccharides $(0.09 \%)$; T5) $\beta$ glucan/mannan-oligosaccharides $(0.1 \%)+$ fructooligosaccharides $(0.03 \%)+$ galactooligosaccharides $(0.07 \%)$; and T6) $\beta$-glucan/mannan-oligosaccharides $(0.1 \%)+$ fructooligosaccharides $(0.05 \%)+$ galactooligosaccharides $(0.05 \%)$.

$\mathrm{a}, \mathrm{b}$ differences according to chi-squared test $(\mathrm{P}<0.1)$. 
A difference was found in fatty acid profile between T4 ( $\beta$-glucan/mannanoligosaccharides $(0.1 \%)+$ fructooligosaccharides $(0.01 \%)+$ galactooligosaccharides $(0.09 \%) \quad$ and control, with advantages to the former. This scenario indicates the potential participation of combinations of $\beta$-glucans/mannanoligosaccharides with fructooligosaccharides + galactooligosaccharides in improving the fatty acid profile in the caecum, which is actually comparable to using butyrate.

Dietary supplementation with organic acids, among which butyrate, classically modulates the profile of VFAs in the caecum, as observed by Callegari et al. (2016), who found that, regardless of the combination of acids and their presentation - whether encapsulated or as a salt - in the caecum, acetic, butyric, and propionic acids where present at higher amounts than in the control group (with no fatty acid supplementation).

It can also be observed that the results found for the group treated with butyrate had a similar VFA production scenario to that obtained by Mallo et al. (2012), who observed higher concentration of butyric acid in the colon when assessing the effects of adding encapsulated sodium butyrate and butyric acid monoglyceride to the diet of piglets weaned at 21 days of age. These results are attributed to the changes in microbial population in the small and large intestines, which favors the survival of lactic acid bacteria and reduces the population of pathogenic bacteria (Michiels et al., 2009), which impact the VFA profile.

The results obtained in increasing VFAs through the action of prebiotics also match the findings by $\mathrm{Wu}$ et al. (2017), who, when adding isomaltooligosaccharides $(6 \mathrm{~g} / \mathrm{kg})$ to the diet of piglets between 21 and 49 days old, reported a significant increase in the content of total fatty acids in the caecum and colon compared to the control group. As discussed, prebiotics favor the production of short-chain fatty acids in the caecum, which, in turn, promote the proliferation and differentiation of epithelial cells (Liu et al., 2018).

The higher production of short-chain fatty acids (acetic, propionic, and butyric) inhibits the development of pathogens through the reduction in intestinal $\mathrm{pH}$, which makes the medium improper for the multiplication of pathogens, or through the direct effect of acids on Escherichia coli, Clostridium spp., and Salmonella sp., thus resulting in better activity of digestive enzymes, use of feed nutrients, and intestinal health (Rodrigues et al., 2017).

Alternative treatments led to similar performance as colistin, albeit with better results in diarrhea control, particularly in T4 and T5, and better VFA production rates, which indicates its benefit and consumer safety by avoiding the risks of colistin inducing bacterial resistance.

\section{CONCLUSION}

The supplementation of different compositions and concentrations of prebiotics and butyric acid in the diet of nursery piglets proved viable for animal performance and properly replaces colistin as a growth promoter, in addition to having positive effects on diarrhea control and volatile fatty acid production in the caecum.

\section{ACKNOWLEDGEMENTS}

The authors wish to thank the company Yes Sinergy for their technical support.

\section{REFERENCES}

ASSIS, S.D.; LUNA, U.V.; CARAMORI JUNIOR, J.G. et al. Desempenho e características morfo-intestinais de leitoas desmamadas alimentadas com dietas contendo associações de mananoligossacarídeo. Arch. Vet. Sci., v.19, p.3341, 2014.

BIAGI, G.; PIVA, A.; MOSCHINI, M. et al. Performance, intestinal microflora, and wall morphology of weanling pigs fed sodium butyrate. J. Anim. Sci., v.85, p.1184-1191, 2017.

BUDIÑO, F.E.L.; CASTRO JÚNIOR F.G.; OTSUK, I.P. Adição de Frutoligossacarídeo em dietas para leitões desmamados: desempenho, incidência de diarreia e metabolismo. Rev. Bras. Zootec., v.39, p.2187-2193, 2010.

CALLEGARI, M.A.; NOVAIS, A.K.; OLIVEIRA, E.R. et al. Microencapsulated acids associated with essential oils and acid salts for piglets in the nursery phase. Semin. Ciênc. Agrár., v.37, p.2193-2208, 2016. 
CHIOFALO, B.; LIOTTA, L.; LO PRESTI, V. et al. dietary supplementation of free or microcapsulated sodium butyrate on weaned piglet performances. J. Nutr. Ecol. Food Res., v.2, p.1-8, 2014.

ERWIN, E.S.; MARCO, G.J.; EMERY E.M. Volatile fatty acid analyses of blood and rumen fluid by gas chromatography. J. Dairy Sci., v.44, p.1768-1771, 1961.

GAVIOLI, D.F.; OLIVEIRA, E.R.; SILVA, A.A. et al. Efeito de promotores de crescimento para suínos sobre o desempenho zootécnico, a qualidade intestinal e a eficiência da biodigestão dos dejetos. Semin. Ciênc. Agrár., v.34, p.39833998, 2013.

GEBBINK, G.A.R.; SUTTON, A.L.; RICHERT, B.T. et al. Effects of addition of fructooligosaccharide (FOS) and sugar beet pulp to weanling pig diets on performance, microflora and intestinal health. Swine Day, p.53-59, 1999. Available in: http://www.ansc.purdue.edu/swine/swineday/sda y99/9.pdf. Aceessed in: 26 Mai. 2019.

GRELA, E.R.; SEMENIUK, V.; CZECH, A. Efficacy of fructooligosaccharides and mannanoligosaccharides in piglet diets. Med. Weter, v.62, p.762-766, 2006.

HANCZAKOWSKA, E.; NIWINSKA, B.; GRELA, E.R. et al. Effect of dietary glutamine, glucose and/or sodium butyrate on piglet growth, intestinal environment, subsequent fattener performance, and meat quality. Czech. J. Anim. Sci., v.59, p.460-470, 2014.

HUTKINS, R.W.; KRUMBECK, J.A.; BINDELS, L.B. et al. Prebiotics: why definitions matter. Curr. Opin. Biotechnol., v.37, p.1-7, 2016.

JAYARAMAN, B.; NYACHOTI, C.M. Husbandry practices and gut health outcomes in weaned piglets: a review. Anim. Nutr., v.3, p.205211,2017

KOTUNIA, A.; WOLINSKI, J.; LAUBITZ, D. et $a l$. Effect of sodium butyrate on the small intestine development in neonatal piglets feed by artificial sow. Natl. J. Physiol. Pharm. Pharmacol., v.55, p.59-68, 2004.

LIN, H.C.; VISEK, W.J. Colon mucosal cell damage by ammonia in rats. J. Nutr., v.121, p.887-893, 1991 .
LIU, Y.; ESPINOSA, C.D.; ABELILLA, J.J. et al. Non-anti biotic feed add itives in diets for pigs: a review. Anim. Nutr., v.4, p.113-125, 2018.

LUNA, U.V.; CARAMORI JÚNIOR, J.G.; CORRÊA, G.S.S. et al. Mananoligossacarídeo e ß-glucano em dietas de leitões desmamados. Arq. Bras. Med. Vet. Zootec., v.67, p.591-599, 2015.

MALLO, J.; BALFAGON, A.; GRACIA, M. et al. Evaluation of different protections of butyric acid aiming for release in the last part of the gastrointestinal tract of piglets. J. Anim. Sci., v.90, p.227-229, 2012.

MARKOWIAKAUTOR, P.; ŚLIŻEWSKA, K. O papel dos probióticos, prebióticos e simbióticos na nutrição animal. Gut Pathog., p.10-21, 2018.

MAZZONI, M.; LE GALL, M.; DE FILIPPI, S. et al. Supplemental sodium butyrate stimulates different gastric cells in weaned pigs. J. Nutr., v.138, p.1426-1431, 2008.

MENDES, C.A.C.; BURDMANN, E.A. Polymyxins: review with emphasis on nephrotoxicity. Rev. Assoc. Med. Bras., v.55, p.752-759, 2009.

MICHIELS, J.; MISSOTTEN, J.A.; FREMAUT, D. et al. In vitro characterization of the antimicrobial activity of selected essential oil components and binary combinations against the pig gut flora. Anim. Feed Sci. Technol., v.151, p.111-127, 2009.

MOQUET, P.C.A.; SALAMI, S.A.; ONRUST, L. et al. Butyrate presence in distinct gastrointestinal tract segments modifies differentially digestive processes and amino acid bioavailability in young broiler chickens. Poult. Sci., v.97, p.167-176, 2017.

PARK, J.H.; LEE, S.I.; KIM, I.H. Effect of dietary $\beta$ glucan supplementation on growth performance, nutrient digestibility, and characteristics of feces in weaned pigs. J. Appl. Anim. Res., v.46, p.1193-1197, 2018.

PIVA, A.; PIZZAMIGLIO, V.; MORLACCHINI, M. et al. Lipid microencapsulation allows slow release of organic acids and natural identical flavors along the swine intestine. J. Anim. Sci., v.85, p.486-493, 2007. 
RODRIGUES, D.J.; BUDIÑO, F.E.L.; PREZZI, J.A. et al. Carcass traits and short-chain fatty acid profile in cecal digesta of piglets fed alfalfa hay and fructooligosaccharides. Rev. Bras. Zootec., v.46, p.331-339, 2017.

ROSTAGNO, H.S.; ALBINO, L.F.T.; DONZELE, J.L. et al. 3.ed. Tabelas brasileiras para aves e suínos: composição de alimentos e exigências nutricionais. Viçosa: UFV, 2011. $252 \mathrm{p}$.

SANTOS, V.M.; THOMAZ, M.C.; PASCOAL, L.A.F. et al. Digestibilidade, desempenho e características morfofisiológicasdo trato digestório de leitões desmamados sob dietas com mananoligossacarídeo. Pesqui. Agropecu. Bras., v.45, p.99-105, 2010.
SILVA, L.P.; NÖRNBERG, J.L. Prebióticos na nutrição de não-ruminantes. Ciênc. Rural, v.33, p.983-990, 2003.

VASSALO, M.; FIALHO, E.T.; OLIVEIRA, A.I.G. et al. Probióticos para leitões dos 10 aos 30 $\mathrm{kg}$ de peso vivo. Rev. Bras. Zootec., v.26, p.131138, 1997.

VISENTINI, P.R.S.; BERTO, D.A.; HAUPTLI, L. et al. Adição de frutooligosacarídeos e olaquindox à dieta sobre o desempenho, microbiota intestinal e parâmetros sanguíneos de leitões desmamados. Cad. Téc. Vet. Zootec., v.15, p.570-576, 2008.

WU, Y.; PAN, L.; SHANG, Q.H. et al. Effects of isomalto-oligosaccharides as potential prebiotics on performance, immune function and gut microbiota in weaned pigs. Anim. Feed Sci. Technol., v.230, p.126-135, 2017. 